\title{
Kolokvium sv. Tomáš Akvinský a politika (Saint Thomas d'Aquin et la Politique)
}

FR. B E NEDIKT MOHELNÍKO P

Ve dnech 28.-29. ledna 2013 proběhlo v prostorách Institut Catholique v Toulouse mezinárodní odborné kolokvium organizované Revue Thomiste a Institut Saint-Thomas-d'Aquin (ISTA). Série těchto kolokvií pořádaných obvykle jednou za dva roky začala před dvaceti lety při př́ležitosti oslav stého výročí existence Revue Thomiste.

Letošní kolokvium, ostatně jako ta předchozí, se věnovalo dílu sv. Tomáše Akvinského v duchu toulouské tomistické školy, která staví na třech pilíríich: Návrat k textu sv. Tomáše, který musí být čten a vykládán v původním historickém kontextu; identifikace principů, které strukturují Tomášovo myšlení; analogická aplikace principů na současné otázky. Čím správnější a důkladnější je pochopení základů, tím odvážnější diskuzi je možné vést se současností. Kolokvium tentokrát prezentovalo současný stav bádání v otázce politického myšlení sv. Tomáše Akvinského a konfrontovalo ho s aktuálními otázkami dneška.

Program kolokvia zahrnoval pohledy na probíranou problematiku z různých úhlů. Dva intenzivní studijní dny tak byly rozděleny do několika bloků, z nichž každý akcentoval některý z dílčích přístupů vycházející z odborné specializace jednotlivých interventů. První blok nazvaný „Homo est naturaliter animal civile: antropologie a politika“ studoval myšlení sv. Tomáše v jeho středověkém kontextu. Nejprve se ujal slova Ruedi Imbach ${ }^{8}$ a přednesl přednášku „Recepce Aristotelovy Politiky ve 13. stol.“ Po něm následoval příspěvek Gilberta Dahana ${ }^{9}$ na téma „Politika čerpající z Písma svatého? Exegeze a politika u sv. Tomáše“" Tyto první dvě přednášky měly poukázat na prameny politického myšlení sv. Tomáše. Politickou antropologii sv. Tomáše představily další dva příspěvky. Jako první dostal slovo Serge-Thomas

8 Ruedi Imbach, původem Švýcar, začal svou akademickou dráhu jako vyučující dějin středověké filozofie na univerzitě ve Fribourgu. Od roku 1999 je profesorem této disciplíny na Sorbonně v Paříži.

9 Gilbert Dahan je francouzský historik náboženských věd, ředitel CNRS a působí na École pratique des hautes études. Je především uznávaným medievistou a znalcem historické exegeze Písma. 
Bonino OP, ${ }^{10}$ aby vytěžil důležité poznatky z analýzy uspořádání světa démonů v přednášce „Andělské společnosti“. Středověké spekulativní téma mu poskytlo skvělé východisko pro přiléhavou aktualizaci nabízející kritéria pro posouzení současného vnímání a praktikování politiky. Dále přednesl svůj příspěvek Philippe Vallin ${ }^{11}$ s názvem „Proč je člověk politickým tvorem?“.

Druhý blok nesoucí titul „Věda obce“ soustředil pozornost účastníků kolokvia na dva zásadní pojmy nutně spojené s politickým myšlením. François Daguet OP12 prezentoval předmět svého dlouhodobého odborného zájmu, totiž „Společné dobro“. Na něho navázal Michel Bastit ${ }^{13} \mathrm{~s}$ prríspěvkem „Politika a etika. Obecná spravedlnost“. Oba přednášející se věnovali jak učení sv. Tomáše Akvinského, tak statutu těchto klasických témat v současné reflexi.

Třetí blok byl nazván „Obec, bytí, církev“ a zahrnoval opět dva příspěvky, tentokrát dvou profesorů ze švýcarského Fribourgu. François-Xavier Puttalaz ${ }^{14}$ zahájil přednáškou „Politika a metafyzika“, ve které se věnoval analogiím mezi metafyzikou a politikou s otázkou, zda je politika přímou aplikací metafyzických principů, či zda se metafyzika může chápat jako ideální projekce politických struktur. Eklesiolog Benoît-Dominique de La Soujeole $\mathrm{OP}^{15}$ se v přednášce „Je církve společnost?“ zaměřil na jistým způsobem sporný termín společnost, či spíše „dokonalá společnost“, chápaný jako politická kategorie používaný v teologické reflexi tajemství církve.

Čtvrtý blok pod titulem „Současná recepce politického myšlení sv. Tomáše“ přenesl těžiště kolokvia především do moderní doby.

10 Serge-Thomas Bonino OP, dlouholetý ředitel Revue Thomiste, vyučující na dominikánském studiu a Institut Catholique v Toulouse. Je členem Papežské akademie sv. Tomáše Akvinského. Je rovněž členem papežské Mezinárodní teologické komise a od roku 2011 také jejím generálním sekretářem.

11 Philippe Vallin, diecézní kněz, vyučuje systematickou teologii na katolické teologické fakultě ve Strasbourgu. Byl sekretářem Doktrinální komise francouzských biskupů.

12 François Daguet OP vyučuje systematickou teologii na dominikánském studiu v Toulouse a je ředitelem Institut Saint-Thomas-d'Aquin.

13 Michel Bastit vyučuje na Université de Bourgogne v Dijonu, je zakladatelem Société Internationale de Philosophie Réaliste. Věnuje se starověké a středověké filosofii.

14 François-Xavier Puttalaz vyučuje na teologické a filozofické fakultě university ve Fribourgu. Je specialista na středověkou filozofii, vědecky se angažuje také v oblasti filozofické antropologie a bioetiky. Českému čtenáři je přístupná společná kniha PUTTALAZ, Francois-Xavier - IMBACH, Ruedi. Povoláním filosof. Siger z Brabantu a středovéká universita. Praha: Oikúmené, 2005.

15 Benoît-Dominique de La Soujeole OP, francouzský dominikán, je profesor dogmatické teologie na teologické fakultě university ve Fribourgu. Jeho specializací je eklesiologie. 
Vittorio Possenti ${ }^{16}$ pronesl přednášku „Tomismus a politické myšlení u J. Maritaina“ a Emmanuel Perrier $\mathrm{OP}^{17}$ přednášku „Finalita politických společností u sv. Tomáše a v současných teoriích “ Tento poslední blok uzavřel Charles Morerod OP18 svým př́ispěvkem o kardinálu Charlesu Journetovi a jeho postojích k vážným politickým a společenským problémům $\mathrm{v}$ době druhé světové války $\mathrm{v}$ souvislosti se švýcarskou neutralitou.

Kolokvium završila přednáška pro širší veřejnost, kterou pod názvem „Aktualita politiky sv. Tomáše Akvinského“ přednesl Pierre Mannet. ${ }^{19}$ Tento významný současný francouzský filosof zaujal četné posluchače podrobnou analýzou současné politické filozofie, a v důsledku také současné společnosti. Ve svém brilantním vystoupení poukázal na nutnost rozlišovat mezi zákonem a právem. Zatímco zákony je naše společnost zahlcena, pojem práva, které je garantem vytváření řádu ve společnosti, se vytrácí.

Ve vedení kolokvia se střídali členové redakce Revue Thomiste a ISTA. Po každém bloku přednášek následovala krátká diskuze, která umožnila výměnu názorů jak mezi odborníky, tak zodpovězení otázek dalších účastníků. Absenci jednoho z ohlášených interventů vyplnil kulatý stůl, k němuž pod vedením Serge-Thomase Bonina OP usedli Vittorio Possenti, François-Xavier Puttalaz, Michel Bastit a François Daguet OP. Debatéři se pokusili formulovat odpověd' na otázku, jak přenést principy politického myšlení sv. Tomáše do současného kulturního a společenského prostředí a soudobé politické filozofie. Dialog mezi těmito dvěma světy je stejně tak žádoucí a přínosný jako obtížný.

Součástí kolokvia byla slavnostní mše sv. v den liturgické slavnosti sv. Tomáše Akvinského v toulouském kostele Les Jacobins, bývalém

16 Vittorio Possenti vyučoval politickou filosofii na Università Ca’ Foscari v Benátkách. Je autorem více než 25 knih a stovky esejů v oblasti politického myšlení, etiky, ontologie. Je členem italské Národní komise pro bioetiku, Papežské akademie pro sociální nauku a Papežské akademie sv. Tomáše Akvinského.

17 Emmanuel Perrier OP vyučuje systematickou teologii na dominikánském studiu v Toulouse. V letech 2009-2011 byl ředitelem Revue Thomiste.

18 Charles Morerod OP byl do nedávna rektorem Papežské university sv. Tomáše Akvinského v Římě (Angelicum), členem a generálním sekretářem Mezinárodní teologické komise. Od prosince 2011 je biskupem diecéze Fribourg-Ženeva-Lausanne.

19 Pierre Mannet, francouzský filozof a profesor politické filozofie, je od roku $1991 \mathrm{di}$ recteur d'études na École des hautes études en sciences sociales a také Centre de recherches politiques Raymond Aron. Je asociovaným profesorem na Boston College (Massachusetts, USA). Mezi jeho nejvýznamnější tituly patří Naissances de la politique moderne: Machiavel - Hobbes - Rousseau. 
klášterním kostele dominikánů, kde jsou uloženy světcovy ostatky. Velmi hojně navštívené liturgii předsedal Mons. Robert Le Gall, arcibiskup Toulouse. Kázání pronesl Charles Morerod, biskup Fribourgu, Ženevy a Lausanne. Po skončení mešní liturgie následovalo tradiční procesí s relikviářem s ostatky sv. Tomáše $\mathrm{v}$ nádherné kvadratuře bývalého kláštera. Liturgické slavení vneslo do převážně studijního programu kolokvia duchovní rozměr, který nelze chápat jen jako vhodný doplněk, ale naopak jako integrální součást přístupu k teologickému bádání v duchu sv. Tomáše Akvinského a jeho následovníků.

Pořadatelé si byli dobře vědomi také některých mezer, které v programu kolokvia nevyhnutelně musely vzniknout, jako např. zkoumání tomistického myšlení v průběhu asi šesti století mezi sv. Tomášem samotným a moderní dobou. Především scholastika 15. až 17. století by jistě přinesla do celkového obrazu zajímavé elementy.

Sv. Tomáš musí být na prvním místě čten a chápán jako teolog, exegeta a znalec křestanské teologické tradice, což nevylučuje vidět ho jako filozofa ve vlastním smyslu. Nicméně filozofické myšlení sv. Tomáše je neoddělitelné od jeho teologické reflexe a je mu vždy jistým způsobem podřízeno. Tak také politické myšlení sv. Tomáše, jakkoli vychází především z Akvinátova studia Aristotelova spisu Politika, je hluboce zakořeněno $\mathrm{v}$ jeho teologické práci.

Kolokvium ukázalo, že zdaleka ještě není dokončeno studium historického kontextu Tomášova díla a jeho vnitřní provázanost. Stále nepanuje jistota např. o dataci překladů Aristotela, které měl sv. Tomáš k dispozici. Tyto zdánlivé detaily jsou však rozhodující pro přesné zařazení jeho vlastních děl. Nevyčerpaným tématem je také exegetické dílo sv. Tomáše. Moderní badatelé ho stále více doceňují a uvědomují si důležitost biblické teologie v Akvinátově myšlení. Především však kolokvium ukázalo intelektuální potenciál myšlení sv. Tomáše pro současnou debatu i v takových oblastech jako je politická filozofie, a proč nepřipustit tento termín, i politická teologie. Nutnost politické a společenské angažovanosti církve jako celku i jednotlivých věřících výrazně vnímal také dnes už emeritní papež Benedikt XVI. Přínos církve na tomto poli se nemůže omezit na politickou praxi či teoretizaci aktuálních a partikulárních problémů. Aniž by tuto rovinu kolokvium opomíjelo, chtělo se soustředit především na fundamentální otázky, uchopení principů. Setkání filozofů a teologů z církevní i laické sféry vytvářelo inspirativní prostředí pro podrobení kritice tradiční nauky i soudobých trendů, pro hledání způsobů, jak nacházet nejen společné 
myšlenky ale také společný slovník, a v neposlední řadě pro vlastní „politickou“ zkušenost z vytváření odborné a zároveň přátelské pospolitosti. Na plné znění všech př́íspěvků se můžeme těšit v aktech kolokvia, která vycházejí obvykle s ročním odstupem jako speciální číslo pořadatelské Revue Thomiste. 